\title{
Lending Growth As A Fiqh Implication Toward Product Development Of Islamic Bank In Indonesia
}

\author{
Indupurnahayu \\ Lecturer of Magister Program, \\ Ibn Khaldun Bogor University, Indonesia \\ Riris Aishah Prasetyowati \\ Lecturer of Faculty of Economic, \\ Ibn Khaldun Bogor University, Indonesia
}

\begin{abstract}
This study aim to examine the financing growth of Islamic bank in Indonesia with the provisions system and proof that there is a counterclicality and capital smoothing behavior of bank manager, these findings contrast with the results of previous studies on procyclical behavior in loan loss provisions. The objects of this study are Islamic Banks and Islamic Business Unit in Indonesia period of 2000 - 2016. This study specifically estimates a different calculation in every component of discretionary and non-discretionary in Islamic bank financing with the variable control such as, non performance loan/financing, total loan, deposit growth, equity ratio, and total asset. The equation will be tested by using the regression system estimation and the validity tested by Kolmogorov-Smirnov test and Durbin Watson. The result of this study quantitatively proved that there is a pattern of countercyclicality behavior in Islamic bank consistent with compliant Syariah and significantly has positive correlation described by the relation of loan loss provision with the coefficient of GDP growth rate. From this result in accordance with the fiqh platform, for all forms of muamalah is " $a l$ ashlu fil mu'amalah illa al-ibahah yadullu daliil 'alaa tahriimiha" (the origin of everything is allowed unless there is proof that forbid it), which means that by using the theory of fiqh rules the product development of Islamic bank can be done and expanded. The evidence for financing growth is that Islamic bank financing does not depend on the amount of deposit rates, and the coefficient of deposit and financing growth is insignificant and excluded, while the growth of financing and bank capital, GDP, and NPL have a negative and significant correlation. The coefficient of total assets and the growth of financing has a positive and significant correlation that means that Islamic bank managers to be income smoothing behavior.
\end{abstract}

Keywords: countercyclicality, loan loss provision, financing growth, Fiqih Platform, Islamic Lending.

\section{INTRODUCTION}

Islamic Bank in its effort to improve the financing growth should be aware of the risk payment failure in financing that can be input and basis for making the bank's profitability calculation, capital adequacy, solvency, and the calculation of the allowance incentive financing loss reserves (Dermine and Carvalho, 2006). According to Yaziz (2011), to improve financing growth from sharia perspective for financing risk and loan loss provisions in Islamic bank, there are two perceptions: first is the perception of sharia financing risk as a basis for assessing the quality of financing, and the second is the perception of allowance incentive for loan loss provisions used by Islamic bank in achieving a certain goals.

The fact that Islamic bank in expanding its financing shows the behavior of procyclicality. It occurs because the bank managers increase the provisions during the deteriorated time and reduce the provisions during the decent time. So, the implications of procyclicality is provoking 
a financing crisis and then exacerbate the economic recession (Adzis et al., 2015). At the cycle of deteriorates time, the increasing of loan loss provisions will affect the bank's revenue, weaken the bank's capital and reduce the loan eligibility of the debtor. According Soedarmono et al., (2016) loan loss provisions of Islamic bank generally procyclicality. The loan loss provisions decline when economic growth strengthened, and this procyclicality behavior can sharpen the decline of economic growth through the reduction of financing.

This study examines the growth of Islamic bank financing in Indonesia with the provisions system that used in order to obtain the result as a proof that there is a procyclicality behavior and income smoothing behavior of bank manager. This result will be diagnosed in a qualitative analysis based on fiqh platform in order to generate some implications for regulators, society, and further research. To improve the financing growth, Islamic bank can do such product development, innovation, and diversification based on the principles of sharia, without having constrained by risk, capital adequacy, reserve requirements, and the bank's solvency. So, it is expected that operational activities of Islamic bank in Indonesia not only for the benefit of capitalist.

\section{Theory of Sharia Financing}

\section{LITERATURE REVIEW}

The theory that relating to the classification of sharia financing explained that musharaka, mudharaba, murabaha, salam, istishna, ijara, and qardh is the classification of the main agreement contract that provided for Islamic bank customers. This classification distinguished by: non-debt sharia financing model, namely musyaraka and mudharaba; debt sharia financing model, namely murabaha, salam, istihsna and Ijara (Kahf, 2005). Other forms of financing classification by Uthmani (2002) define it based on: 1) Pure sharia financing model, namely musharaka, mudaraba, salam, and istishna; 2) Artificial/Reformed sharia financing model, namely: murabaha and Ijara. This study added the financing that is actually the real loan, according to sharia principles, namely loans al-qardh al-hasan.

Before stipulate the determinants of the sharia financing growth, there are two principal opinions that Islamic banks adhere to sharia rules on each contract, even though the artificial/reformed financing model of less Sharia than the pure financing model (El-Gamal, 2000). On the contrary opinion said that ijara and murabaha financing model is not ideal for Islamic bank and it is only used as a device to escape from interest rates (Uthmani, 2002). mudharaba and musyaraka are based on the principle of profit and loss sharing, and this is the model that is the most needed in Islamic banks. When using both of these instruments, it does not create a debt for the whole community, the profits divided equally between capital and labor.

Another argument proposed by the researcher who un-feel necessary to connect with Islamic finance industry. Ordody de Ordod (2001) shows that the economic balance and full employment guaranteed by unlimited individuals based on facts that are recommended before interest rates are set. Ordod (2001) argue that the rigidity of interest rate toward fluctuation led to disequilibrium and inflation. Shiller (2003) proposed the notion that the borrower's problem in conventional interest rate stipulated in his debt is directing on the issue of personal bankruptcy.

Based on the opinions above, it necessary to determine the variables for calculating the financing growth in Islamic bank:

1. LLP non-discretionary as a predictor based on research of risk determination in Islamic bank (Agmad, 2003; Hassan 1992.1993; Hassan et al.,1994; Shireve and Dahl, 1997; 
Angbazo et al.,1998), in this component, variables that describes bank's LLP are included, such as non performing loan, total loan, and the growth of gross domestic product as variables control of loan risk in the NLLP component.

2. The third-party fund or deposit is the total liabilities from the balance sheet report. Total liabilities are managed based on the principle of profit and loss sharing for investment accounts, saving accounts and wakala deposits using special reserve for his profit and loss sharing (Taktak et al. 2010) that is profit equalization reserve (PER) and investment risk reserve (IRR), which are the two mechanisms that actively reduce the volatility of the rate of return in deposits investment including the consequence in his return equalization (Sundarajan , 2005; Khan Ahmed, 2001; Archer et al., 2010). This is executed by Islamic banks to avoid the abandonment of massive withdrawals risk that are a common occurrence that causes a potentially bank run.

3. Equity is the number of outstanding shares multiplied by the stock price at the beginning of each year. For Islamic bank, total equity is the sum of the first tier capital (Tier-1 capital) and second tier capital (Tier-2 Capital), where the second tier capital needed to capture the motives of capital management that is expected to affect loan loss provisions negatively. (Ashraf, et al., 2000).

4. Total assets classified based on sharia contract such as asset based on sale-purchase contract, asset based on leasing, and equity investment. Islamic bank do the logarithm of total asset to capture bank investment from each types of bank.

\section{Theory of Income Smoothing}

Zoubi and Al-Khazali (2007) in his research in the Gulf countries, noting that there is a positive correlation between the LLP and Income. This positive correlation means that managers of Islamic banks also use the LLP to manage earning, now and in the future. Previous research has hypothesized that bank managers have an incentive to apply income smoothing (Misman and Ahmad, 2011). Ashraf et al. (2015) revealed that the bank's earning management in application of LLP is influenced by the nature of the bank, because the results showed the issue about management and bank's governance that were listed.

\section{Theory of Procyclicality Behaviour}

Al-Khayat (2013) who did research in 15 countries of the Gulf Cooperation Council (GCC) such as Bahrain, Kuwait, Oman, Qatar, Saudi Arabia, and United Arab Emirates (UAE), demonstrated by using the determinant of LLP on Islamic banks, namely : Tier-1 capital, NPL and Size, revealed that in fact, the Islamic Bank has a prudent behavior patterns and not procyclis, and Islamic bank does not perform the income-smooth, except when Islamic banks experiencing the negative earning, and this action is also carried out as a countercyclical tool. Research of Boulila et al. (2010) tested the hypothesis the income smoothing of Islamic banks show typical characteristics environment: First, Islamic banks governed by Islamic principles (Sharia) using a risk-sharing mechanism among investors. Second, the regulations related to sharia accounting that does not restricted the use of dynamic provisioning, so the Islamic banks have a tendency to establish the allowance to absorb losses in the future.

\section{The Fiqh Platform}

According to Malikiyah, murabaha or financing in Islamic bank is mutually beneficial, it means the seller must notify the buyer about the product price he bought and determine the additional profit. In Al-Qur'an Chapter An-Nisaa verse 29 stated:

"O you who have believed, do not consume one another's wealth unjustly but only (in lawful) business by mutual consent. And do not kill your selves (or one another). Indeed Allah is to you ever Merciful." (An-Nisaa, 29) 
From Abi Sa'id Al Khudri, in Hadith Rasulullah SAW said: "Indeed, selling has to do with mutual fond and mutual willingly". (HR. Ibnu Majah) (Al Zuhaily, p.703). The majority of fiqh scholars agree that the supporting fiqh rule used for financing contract in Islamic bank is "al ashlu fil mu'amalah al ibahah illa yadullu dalil 'alaa tahriimiha" which means the origin of everything is permitted unless there is a proof that forbid it (haram) (Qal'ah Jiy, p.11). This rule is in accordance with DSN fatwa No.90/DSN-MUI/XII/2013. Another rule that support the financing theory are "adhdararu yuzaal" which means the danger of heavy load, the loss shall be omitted (Al Suyuthi, p.16). "Al ashlu fil 'uquud wa syuruth al ibahah" which means basically all forms of contract and terms are permitted to be executed. "Adhdhararu yudfa" which means any harm shall be avoided wherever it possible (Al Zarqa, p.207). "Al haajatu tanzilu manzilata dharurati 'aammatan kaanat aw khaasah" which means the urgent needs can be in emergency position, both generally and specifically (MUI, p.79-92).

The rule of benevolent loans al qardhul hasan in sharia is "kullu qardhin jarra naf'an fahuwa riba" which means any debts that bring benefits to the indebted is riba (Ramadhan, p.300). From that rule and legal source, the theory of musyaraka, mudharaba, istishna, salam, ijarah, murabaha and qardh in Islamic bank must be in accordance with the fiqh theory, which is in every economic activity has to do with mutual fond ('an taradhin minkum), equitable ('al 'adaalah), and no adverse (laa dharar walaa dhirar). Related to the practice of murabaha in Islamic bank, financing product for purchase of investment goods, both domestically and abroad through (L/C) and ask for a down payment from customer and get discount from suppliers. Legally, it can be executed referring to the grand theory of fiqh rule "al ashlu fil mu'amalah al ibahah illa yadullu daliil 'ala tahriimiha". Likewise in the operational to increase profitability and expand its business, Islamic bank can develop their products through the sale and purchase contract that is permitted by Islam. It can be implemented in another sector for productive activity, so the role of Islamic bank as intermediary institution has done well and not just focus on financing.

Profit in Islamic bank is in accordance with the characteristics of Islamic finance or murabaha called agreed profit (Rushd, p.293). Another theory states that benefit ratio determined by agreement, not by the portion of deposit capital (Al-Kasani; Ash Syarbini \& Al Bahuti). The legal basis in the fiqh rule that used for profit and risk in accordance with Islamic principles, mentioned in the Hadith "wa laa maa lam ribhu yudhman" which means there should be no profit without risking loss (Ahmad 6831, Nasa'i 4647). "Al ghurmu bil ghunmi" which means loss and profit are borne and shared (Ramadan, p.461). From Urwah Al Bariqi RA, state that Rasulullah SAW gave him one dinar to buy a goat. With that one dinar, he bought two sheep's and resells one goat worth in one dinar. Then he came to the Prophet while bring one goat and one dinar. By looking at this, the Prophet prays for his blessing (Hadith of Bukhari). A Muslim scholar, Al-Ghazali in his book Al-Ihya Ulumuddin does not dismiss the fact that profit is the main motive of trade. But he gives a lot of emphasis on business ethic, which is this ethic derives from Islamic values (Al Amin \& Amalia, 2010). From previous explanation, can be conclude that profit in Islam is permitted as long as no harm or injustice and not hurt each other according to Islamic principles.

One of the rules in Muamalah concept in Islam is about riba. Riba means an excess or addition. Islam strictly prohibits riba, Al-Qur'an as a legal basis clearly stated in the Chapter of AlBaqarah verse 275: "wa ahallahul ba'i wa harrama riba" (But Allah has permitted trade and has forbidden riba). Also in Chapter of An-Nisaa verse 161 stated:

"And (for) their taking of riba while they had been forbidden from it, and their consuming of the people's wealth unjustly. And we have prepared for the disbelievers among them a painful punishment." (An-Nisaa, 161) 
The fiqh rule that used for riba: "laa tadzlimuuna walaa tudzlamun" means that do not persecute nor persecuted (Haroen, 2000). Referring to Islamic legal basis and Islamic fiqh theory about the prohibition of riba, clearly that riba will never bring mashlahat or goodness. Not only for Muslims but for the whole human race, and even led to the danger or harm greater economic sustainability and life.

\section{METHODOLOGY}

The objects of this study are Islamic Banks and Islamic Business Unit in Indonesia period of 2000 - 2016. The data used as an instrument measurement of financial statement obtained from Islamic Bank Statistics Report from 2000 - 2016 from Bank Indonesia and the Financial Services Authority. The appendix contains of tables of statistical data processing results.

This study uses the approach of Bouvatier and Lepetit (2008) to observe the impact of nondiscretionary and discretionary components in loan loss provisions to the financing growth of Islamic bank. We also specifically estimate ranging from setting a different definition from the calculation of each component of discretionary and non-discretionary on the financing of Islamic bank. The equation we made follows the approach of Bouvatier and Lepetit (2012) as follows:

$$
T L_{t}=\beta_{0}+\beta_{1} N D I S C_{t}+\beta_{2} D E P_{t}+\beta_{3 c} C A R_{t-1}+\beta_{4} T A_{t-1}+u_{t}
$$

The $F_{t}$ is the sharia financing growth. NDISCt in this research is non-discretionary component that is expected to affect financing growth negatively if allegedly the procyclicality behavior consistent with the system of backward-looking loan loss provisioning. The increased of costs from sharia financing is shown with the loan loss provisions, thus encouraging banks to reducing incentives to increase the financing. We also set the variable control such as: deposits growth $D E P_{t}$, equity ratio $\mathrm{CAR}_{t-1}$, and to measure the size of Islamic banks by using the logarithm of Total Assets $T A_{t-1}$. As well as the influence of time on the level of gross domestic gross product (GDP) also we add to control the changes in macroeconomic conditions.

This paper focus on the measurement calculation of several non-discretionary component to test the robustness of the results, so the equation that used to represent hypotheses for the behavior patterns of procyclicality and income smoothing behavior in Islamic banks refer to the study of Bouvatier and Lepetit (2012) as follows:

$$
N D I S C_{t}=\alpha_{1} L L P P_{t-1}+\alpha_{2} N P l_{t}+\alpha_{3} \Delta N P L_{t}+\alpha_{4} T L_{t}+\alpha_{5} G D P_{t}+\alpha_{6} T A_{t}
$$

In the system of backward-looking provisioning show the primary correlation of $\boldsymbol{N D I S C}_{\boldsymbol{t}}$ in line with $\mathbf{N P \boldsymbol { L } _ { t }}$ that is the ratio of non-performing financing toward total asset in the end of year $t$, and the first ddeviation (delta) from $\mathbf{N} \boldsymbol{P} \boldsymbol{L}_{t}\left(\boldsymbol{\Delta} \mathbf{N P L _ { t }}=\boldsymbol{N} \boldsymbol{N} \boldsymbol{L}_{\boldsymbol{t}}-\boldsymbol{N P L _ { t - 1 } )}\right.$ as a explanatory variable.

These two variables are good indicators to indetify losses in the financing portfolio of Islamic bank. This variable will show a positive correlation with the loan loss provisions. We add the failure risk for the entire financing portfolio, measured by the ratio of total net financing toward total assets $\boldsymbol{T} \boldsymbol{L}_{\boldsymbol{t}}$, these variables showed a positive correlation. We consider the rate of gross domestic product growth $\boldsymbol{G D P}_{\boldsymbol{t}}$ which has a negative correlation with loan-loss provisions. Because of the feasibility of customer's financing Islamic banks depend on economic conditions. Then we also consider the current ratio of bank earnings and loan loss 
reserve toward total asset $\boldsymbol{T A}_{\boldsymbol{t}}$ to examine whether Islamic banks use loan loss provisions for the smoothing income.

For methodology estimation used OLS to test the equation, this estimation known as regression estimation. The combination of the two equations, are: the original equation and the transformation equation. The transformation equation can be the first difference for the original equation. The equation instrument applied only to lag of dependent variable $\left(L L P_{t-1}\right)$. For another variable considered as exogenous.

Validity estimation tested using Kolmogorov- Smirnov test and Durbin Watson that examine the autocorrelation and fixed effect. We also guarantee that in this test there is no multicollinearity problem and correlation matrix.

\section{Quantitative Result}

\section{RESULT}

Result of normality test of Nondiscreation LLP and Discretion LLP which shows managerial goals in income smoothing, capital management, and signaling as follows:

Table 1. NLLP Variable Normality Test Output.

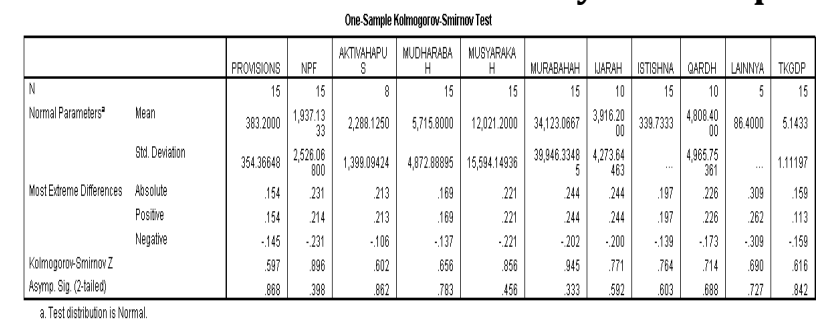

Table 1 shows All NLLP variables used show values greater than 0.05 means that all variables are normally distributed and there is no difference.

Table 2. DLLP Variable Test Output

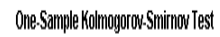

\begin{tabular}{|c|c|c|c|c|c|c|}
\hline & & $\begin{array}{c}\text { MOCA.SETD } \\
R\end{array}$ & LABABERSH & $\underset{N}{\text { LAEADTHHA }}$ & SELLSHLABA & TOTALASGET \\
\hline $\mathbb{N}$ & & 15 & 15 & 15 & 15 & 15 \\
\hline \multirow[t]{2}{*}{ Nommal Palametersis } & Neall & 3,1530000 & 857.3333 & 710.4667 & 96.4667 & $78,947.7333$ \\
\hline & Sto. Devialion & $3,398.95370$ & 999.05346 & $1,244.093998$ & 60999084 & $91,697.248065$ \\
\hline \multirow[t]{3}{*}{ Most Extreme Differences } & Absolde & 305 & .225 & .294 & .320 & .226 \\
\hline & Posiline & 305 & .225 & .294 & .184 & .226 \\
\hline & Neygative & .220 & .202 & .254 & .320 & .200 \\
\hline Kolmogonor-Sminony 2 & & 1.183 & 870 & 1.144 & 1.240 & .874 \\
\hline Asymp. Sig (2-aleded) & & .122 & 436 & .140 & .092 & .420 \\
\hline
\end{tabular}

In quantitative method, the result proved (table 2) that the DLLP variable indicating the bank manager has an attitude of income smoothing, capital management, and signaling is valid and significant to the privisons (LLP).

The result of the regression equation obtained for the correlation and the influence of loan loss provision with non-discretionary component that affect to the financing growth rate also show the countercyclicality and capital management behavior of bank manager. This result is in accordance with Shariah compliance, as follows: 
Tabel 3. Output R Square LLP

Model Summary

\begin{tabular}{|l|c|r|r|r|r|}
\hline $\begin{array}{l}\text { Mode } \\
1\end{array}$ & $\mathrm{R}$ & $\mathrm{R}$ Square & $\begin{array}{c}\text { Adjusted R } \\
\text { Square }\end{array}$ & $\begin{array}{c}\text { Std. Error of } \\
\text { the Estimate }\end{array}$ & $\begin{array}{c}\text { Durbin- } \\
\text { Watson }\end{array}$ \\
\hline 1 & $.994^{2}$ & .988 & .978 & 52.23226 & 2.765 \\
\hline
\end{tabular}

Table 3 shows the LLP variable being eligible and not autocorrelated with Durbin Watson test of $1<2.765<3$. Meaning that TA, GDP, NPF, EAT, and TL contribute to LLP.

Table 4. Output Significance of LLP Variables

ANOVA ${ }^{b}$

\begin{tabular}{|ll|r|r|r|c|c|}
\hline \multicolumn{1}{|c|}{} & \multicolumn{1}{|c|}{$\begin{array}{c}\text { Sum of } \\
\text { Squduares }\end{array}$} & \multicolumn{1}{c|}{ df } & Mean Square & F & Sig. \\
\hline 1 & Regression & 1736232.727 & 6 & 289372.121 & 106.067 & $.000^{\mathrm{z}}$ \\
& Residual & 21825.673 & 8 & 2728.209 & & \\
& Total & 1758058.400 & 14 & & & \\
\hline
\end{tabular}

a. Predictors: (Constant), TA, GDP, NPF, CAR, EAT, TL

b. Dependent Variable: PROVISIONS

Table 4. shows the significance of all LLP variables of $0.000<0.05$

Table 5. Output of LLP Beta Value

Coefficients

\begin{tabular}{|c|c|c|c|c|c|c|}
\hline \multirow[b]{2}{*}{ Mode } & & \multicolumn{2}{|c|}{ Unstandardized Coefficients } & \multirow{2}{*}{$\begin{array}{c}\begin{array}{c}\text { Standardized } \\
\text { Coefficients }\end{array} \\
\text { Beta } \\
\end{array}$} & \multirow[b]{2}{*}{$t$} & \multirow[b]{2}{*}{ Siq. } \\
\hline & & B & Std. Error & & & \\
\hline \multirow[t]{7}{*}{1} & (Constant) & -121.490 & 77.175 & & -1.574 & .154 \\
\hline & NPF & .060 & .039 & .429 & 1.548 & .160 \\
\hline & GDP & 41.187 & 16.388 & .129 & 2.513 & .036 \\
\hline & CAR & -.040 & .029 & -.384 & -1.395 & .201 \\
\hline & EAT & .244 & .117 & 688 & 2.078 & .071 \\
\hline & TL & -.007 & .005 & -2.721 & -1.535 & .163 \\
\hline & TA & .011 & .007 & 2.974 & 1.566 & .156 \\
\hline
\end{tabular}

Table 5 shows the relationship and influence of LLP variable with the following equation:

$$
L L P=-121,5+0,43 N P F+0,13 G D P-0,39 C A R+0,69 E A T-2,72 T L+2,97 T A
$$

This equation shows that loan loss provisions have a common form in the different set of data. NPF ratio and GDP growth rates significantly affect the LLP in all estimation. NPF and GDP have a positive and significant effect, where each 1\% increase in NPF will increase provisions by $0.43 \%$, as well as in GDP with a positive and significant effect, this result contradicts the review of Bouvatier and lepetit (2012). the results of this study show behaviour the forwards-looking provisions system encourage countercyclicality patterns on LLP in Islamic banks in Indonesia this study. The results for discretionary behavior of Islamic bank managers as capital management behavior showed the consistent result with the hypothesis that Islamic banks in Indonesia used LLP for its income smoothing, and the TA coefficient has a positive correlation and significant in all estimations. But TL has a negative correlation with the behavior of Islamic Banks. Dynamic provisioning is theoretically designed for reserve leveling throughout the cycle (acting as a buffer), so that on certain conditions the impact is similar to that of buffer (De Lis and Herrero, 2013). This behavior is in accordance with the shariah compliance that applies to all Islamic Banks.

The resulted of regression equation for financing growth of Islamic banks (Table 2) with dropping the variable of NDISC as follows: 
Tabel 6. Output R Square Loan

Model Summary

\begin{tabular}{|c|c|c|c|c|c|}
\hline Mode & $R$ & RSguare & $\begin{array}{l}\text { Adjusted R } \\
\text { Square }\end{array}$ & $\begin{array}{l}\text { Sitd Error of } \\
\text { the Estimate }\end{array}$ & $\begin{array}{l}\text { Durhin- } \\
\text { Watson }\end{array}$ \\
\hline 1 & $1.000^{3}$ & 999 & 999 & $3,839.869982$ & 2.837 \\
\hline
\end{tabular}

Table 6 shows the growth of loans variable is eligible and autocorrelated with Durbin Watson test of $1<2.837<3$. Meaning that TA, GDP, NPF, CAR, and Provisions (LLP) contribute to the total Loans.

Table 7. Output of Significance of Growth of Loans Variables ANOVA $^{b}$

\begin{tabular}{|ll|r|r|r|c|c|}
\hline Model & & \multicolumn{1}{|c|}{$\begin{array}{c}\text { Sum of } \\
\text { Squares }\end{array}$} & \multicolumn{1}{c|}{ df } & Mean Square & F & Sig. \\
\hline 1 & Regression & $2.392 \mathrm{E} 11$ & 5 & $4.784 \mathrm{E} 10$ & $3.245 \mathrm{E} 3$ & $.000^{2}$ \\
& Residual & $1.327 \mathrm{E} 8$ & 9 & $1.474 \mathrm{E} ?$ & & \\
& Total & $2.394 \mathrm{E} 11$ & 14 & & & \\
\hline
\end{tabular}

a. Predictors: (Constant), TA, GDP, NPF, CAR, PROVISIONS

b. DependentVariable: TL

Table 7. shows that all growth of loan variables are significant at $0.000<0.05$

Table 8. Output of Deposit Variables Excluded Excluded Variables $^{b}$

\begin{tabular}{|c|c|c|c|c|c|}
\hline & & & & & $\begin{array}{l}\text { Collinearity } \\
\text { Statistics }\end{array}$ \\
\hline Model_ & Beta In & $t$ & Siq. & $\begin{array}{c}\text { Partial } \\
\text { Correlation }\end{array}$ & Tolerance \\
\hline $1 \quad$ DEP & 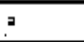 & & & & .000 \\
\hline
\end{tabular}

Table 8 shows the variable Deposits (third party funds) excluded as not significant. This means that profit-based profit-sharing variables can not be included as a variable of the growth of financing. Sources of financing funds in Islamic banks can not rely on third-party funding sources (deposits). Because the contracts and calculations for the results are not equal to the calculation of margin financing at Islamic Bank which has various contracts and types of engagement. These results support the study of Khan and Ahmed, (2001) that the differences in the nature of the composition of assets and liabilities of sharia banks with the principle of profit and loss sharing

Table 9. Output Beta Growth of Loan Value

Coefficients ${ }^{\mathrm{a}}$

\begin{tabular}{|c|c|c|c|c|c|c|}
\hline \multirow{2}{*}{\multicolumn{2}{|c|}{ Model }} & \multicolumn{2}{|c|}{ Unstandardized Coefficients } & $\begin{array}{l}\text { Standardized } \\
\text { Coefficients }\end{array}$ & \multirow[b]{2}{*}{ t } & \multirow[b]{2}{*}{ Sia. } \\
\hline & & $B$ & Std. Error & Beta & & \\
\hline \multirow[t]{6}{*}{1} & (Constant) & 3769.490 & 5994.761 & & .629 & .545 \\
\hline & PROVISIONS & -13.753 & 20.438 & .037 & .673 & .518 \\
\hline & NPF & -1.799 & 1.142 & -035 & -1.575 & .150 \\
\hline & GDP & -673.966 & 1495.574 & .006 &. .451 & .663 \\
\hline & CAR & -5.336 & 1.529 & .139 & -3.489 & .007 \\
\hline & $\mathrm{TA}$ & 1.718 & .116 & 1.205 & 14.825 & .000 \\
\hline
\end{tabular}

a. Dependent Variable: TL 
Table 9. shows the relationship and influence of growth of loan variable with equation as follows:

$$
T L=-0,037 L L P-0,035 N P F-0,006 G D P-0,14 C A R+1,205 T A+U
$$

The coefficient associated with the provisions growth rate represented by LLP showed a significant negative relationship for any $1 \%$ increase in 1\% financing growth of reserves will decrease by $0.04 \%$. For the NPF coefficient shows a negative and significant relationship where every $1 \%$ increase in financing growth will reduce problem financing by $0.04 \%$. In the GDP coefficient shows a negative and significant correlation for each 1\% growth increase in growth occurs when economic growth decreases by $0.006 \%$. The coefficient of CAR is for equity ratio shows negative and significant correlation where every increase of financing growth decrease capital ratio equal to $0,14 \%$ this describes behavior of capital smoothing from bank manager. but the Total Asset coefficient representing size shows a positive and significant correlation which means that every $1 \%$ increase in financing growth increases the total assets of Islamic banks by $1.21 \%$

The positive impact on non-discretionary LLP to financing growth indicates that the system is forward-looking provisions affect the countercyclicality in the Islamic bank financing. It should be when the Islamic bank is in high economic cycles, the LLP is high, so encourage Islamic banks to decrease the financing. In the contrary, when the bank suffered declining in economic cycle, the LLP become low, caused the Islamic banks reduces the incentive in the new financing deals. The sensitivity of financing growth of bank toward non-discretionary LLP bank depends on its banking system.

Table 9 (enclosed) shows the use of NDISC in financing growth reveals that the positive impact on non-discretionary LLP on financing growth is dependent on the effect of GDP growth rate toward LLP. The effect non-discretionary LLP toward financing growth by inserting variable of capital smoothing behavior found that the coefficient results were negative and significant. This results reveal that capital smoothing behavior mitigates the impact of non-discretionary LLP toward financing growth. These results highlight that the capital smoothing behavior is the right solution to mitigate the cyclicality pattern on a non-discretionary LLP and even reduce the impact on financing growth. The right solution comes from Islamic banking regulator to implement dynamic provisioning system in accordance with Islamic banks.

Furthermore, the results of empirical research with quantitative methods will be diagnosed in qualitative method to do prognosis and generates the implications for regulator and society in general according to the fiqh platform.

\section{Qualitative Result}

The growth of Islamic banks in this study is very small and tends to be slow due to the classification model of the primary contract agreement contract provided for Islamic bank customers such as murabaha, mudharaba, musharaka, ijara, salam and isthisna. The fiqh platform which is used for all forms of muamalah is "al ashlu fil mu'amalah illa al-ibahah yadullu daliil "alaa tahriimiha" (the origin of everything is allowed unless there is proof that forbid it), which means that by using the theory of fiqh rules the product development of Islamic bank can be done and expanded.

In practice, Islamic bank only offer murabaha product, but in Islam itself sale-purchase or $b a^{\prime} i$ have a various form that allowed, usable, and can be offered to the public in accordance with 
their needs and abilities. Types of $b a^{\prime} i$ or sale-purchase contract that can be developed in product of Islamic bank are ba'i naqdan, ba'i taqsith, ba'i muajjal, ba'i bi tsaman 'ajil, ba'i wafa, even ba'i tawarruq to provide the choices to the public in accordance with the conditions and problems.

Products from mudharaba contract can develop according to its type such as mudhraba muthlaqa and mudharaba muqayyada. Likewise the development of musyaraka with a variety of partnership contract model such as, musharaka (wujuh, inan, abdan, mufawadhah), muzara'ah, musaqa and mukhabara.

Deposit or saving fund called wadi'ah, the development of product contract can be wadi'ah yad dhamanah and wadi'ah amanah. Ijara contract also can be developed in accordance with the needs and capabilities. The development of ijara contract or lease contract in Islam like pure ijara that is ba'i wal ijara, ijara muntahiya bitamlik or called IMBT, ju'ala and parallel ijara. Islamic banks in Indonesia should be braver and confident in developing sharia products as well as to educate the public about the products of Islamic banks which will be applied and developed, so that Islamic banks can be grew well. With product development of Islamic banks, the public may believe that the interest or riba is not a way out of their problems. The implication of these products development is the advancement of Islamic bank in Indonesia and increase the economic welfare of the Indonesian people.

\section{SUMMARY AND RECOMMENDATION}

1. Quantitatively, the application of backward-looking provision system in financing loss provisions has positive correlation and significant showed a pattern of procyclicality in Islamic banks.

2. The relations of earning current variable with LLP showed the income smoothing behavior of Islamic bank manager who encourages the implementation of backwardlooking provision system.

3. The pattern of cyclicality in non-discretionary component of LLP with income smoothing behavior can not be mitigated, it can even reduce the financing growth of Islamic bank.

4. Qualitatively, the fiqh platform which is used for all forms of muamalah is "al ashlu fil mu'amalah illa al-ibahah yadullu daliil 'alaa tahriimiha" (the origin of everything is allowed unless there is proof that forbid it), which means that by using the theory of fiqh rules the product development of Islamic bank can be done and expanded.

5. There are a lot of forms of the agreement contract that can be developed such as murabaha (ba'i naqdan, ba'i taqsith, ba'i muajjal, ba'i bi tsaman 'ajil, ba'i wafa, even ba'i tawarruq), mudharaba (mudhraba muthlaqa and mudharaba muqayyada), musharaka (wujuh, inan, abdan, mufawadhah), muzara'ah, musaqa and mukhabara, ijara (ba'i wal ijara, ijara muntahiya bitamlik, parallel ijara) and wadi'ah (wadi'ah yad dhamanah and wadi'ah amanah) as long as in accordance with the condition and capability of the customers.

\section{References}

Adzis, Azira Abdul, Herman Shah Anuar and Noor Shahieda Mohd Hishamuddin."Malaysian Commercial Banks: Do Income Smoothing, Capital Management, Signaling, and Procyclicality exist through Loan loss provisions?" International Journal of Economics, Finance and management, Vol.4,No..2, March 2015,pp.68-76.

Ahmad Bin Hanbal, Al Musnad. 1995. Al Qahirah: Dar Al Hadits

Ahmed, A.S.,Takeda,C. and Thomas,S." Bank Loan Loss provisions: a reeaxamination of capital management, earning management and signaling effect", Journal of accounting and Economics, Vol.28 No.1. 1999, pp.1-25. 
Al Arif, Nur Rianto; Amalia, Euis. 2010. Teori Mikroekonomi: Suatu Perbandingan Ekonomi Islam Dan Ekonomi Konvensional. Jakarta: Kencana

Al-Kasany, Bada'i Al Shana'i. t. th. Bairut: Dar Al Kitab Al 'Araby

Al Suyuthi, Jalaludin. 1995. Al Asybah Wa Nazha'ir. Bairut-Libnan: Dar Al Fikr

Al Zarqa', Ahmad. 1989. Syarh Al Qawa'id Al Fiqhiyyah. Damascus: Dar Al Qalam

Anandarajan, A.,Hasan, I. and Loranzo-Vivas, A." The Role of Loan Loss provisions in earning management, capital management, and signaling: The Spanish experience", Advances in International Accounting, Vol.16,2003, pp.4363.

Anandarajan, A.,Hasan, I. and McCarthy, C." Use of Loan Loss provisions for capital, earning management and signaling by Australian banks", journal of Accounting and finance, 47, 2007, pp. 357-379.

Ashraf, Ali., M.Kabir Hassan, and Syed Abul Basher." Loan loss provisioning in OIC Countries: Evidence from conventional vs.Islamic banks", JKAU: Islamic Econ.,Vol.28 No., 2015, pp. 23-59.

Athanasoglou,P.P., Danilidis,I., \& Delisc,M.D." Bank procyclical and output: Issues and policies", Journal of economics and business, 72, 2014, pp. 58-83.

Balla,E., and A. McKenna." Dynamic provisioning: A Countercyclical tool for Loan Loss Reserves", Economic Quarterly,Volume 95, No.4, Fall, 2009, pp.383-418.

Baltagi, Badi H. Econometric analysis of panel data. Chichester: John Wiley and Sons, 2001.

Basel Committee on Banking Supervision 2011. Basel III: A Global regulatory framework for more resilient banks and banking systems. Bank for International Settlement.

Benston,G.J., and Wall,L.D." How should banks account for loan losses?" Journal of accounting and Public policy, vol.24, 2005, pp.81-100.

Bikker,J.A., dan Hu,H.“Cyclical pattern of profit, provisioning and lending of banks. Banca Nazionale del Lavaro Quarterly Review,Vol.55, 2002, pp.143-175.

Bikker,J., and Metzemakers, P. "Bank provisioning behavior and procyclicality", Journal of International Financial Markets, Institutional and Money, Vol.15, 2005, pp.141-157.

Boumediene, Aniss."Is Credit risk really higher in Islamic banks?". The Journal Credit Risk (97-129).

Volume7/Number3,Fall 2011.

Bouvatier, V., and Lepetit, L. (2008)." Banks' procyclical behavior: Does provisioning matter?" Journal of International Markets, Institutions and Money, Vol.18,pp.513-526.

Bouvatier, V., and Lepetit, L. (2011)."Provisioning rules and bank Lending: A theoretical model, Journal of financial Stability,forthcoming.

Bouvatier,V., and L.Lepetit, (2012),"Effect of Loan loss provisions on growth in bank lending: some international comparisons", International Economics, Vol.132,pp.91-116.

Carpenter,S.B., Whitesell, W., Zakrajsejk,E.(2001),"Capital requirement, business loans, and business cycles: An Empirical analysis of potential cyclical effects of the new BIS capital standards, Board of Governors of the federal Reserve System.

Cavallo M. Majnoni G." Do Bank provisions for bad loans in good time?", Empirical evidence and policy implications. World Bank, Working Paper NO.2619. 2001.

DSN MUI, Himpunan Fatwa DSN MUI, (Cipayung-Ciputat:DSN.1427H/2006M), Edisi Revisi, Cet. IV, h.VIII, IX.

Haroen, Nasroen. 2000. Fiqh Muamalah. Jakarta: Gaya Media Pratama

Hidayatullah, Syarif. 2012. Qawa'id Fiqhiyyah dan Penerapannya dalam Transaksi Keuangan Syariah Kontemporer (Mu'malat, Maliyyah Islamiyyah, Mu'ashirah). Jakarta: Gramata Publishing

Majah, Ibnu. T.th. Sunan Ibnu Majah. Dar Al Fikr

Ql'ah Jiy, Rawwas. 1987. Mausu'ah Fiqh Umar Bin Al Khattab, Bairut: Dar Al Nafais

Ramadhan, 'Athiyah. T.th. Mausu'ah Al Qawa'id Al Fiqhiyyah. Al Iskandariyah: Dar Al Qimmah-Dar Al Iman 


\section{APPENDIX}

Tabel 10. Correlation of LLP \& Cyclicality

Correlations

\begin{tabular}{|c|c|c|c|c|c|c|c|c|}
\hline & & PROVISIONS & NPF & GDP & CAR & EAT & TL & TA \\
\hline \multirow[t]{7}{*}{ Pearson Correlation } & PROVISIONS & 1.000 & .870 & .580 & .929 & .946 & .977 & .976 \\
\hline & NPF & .870 & 1.000 & .317 & .911 & .725 & .915 & .922 \\
\hline & GDP & .580 & .317 & 1.000 & .466 & .519 & .464 & .471 \\
\hline & CAR & .929 & .911 & .466 & 1.000 & .862 & .964 & .972 \\
\hline & EAT & .946 & .725 & .519 & .862 & 1.000 & .936 & .927 \\
\hline & TL & .977 & .915 & .464 & .964 & .936 & 1.000 & .999 \\
\hline & TA & .976 & .922 & .471 & .972 & .927 & .999 & 1.000 \\
\hline \multirow[t]{7}{*}{ Sig. (1-tailed) } & PROVISIONS & & .000 & .012 & .000 & .000 & .000 & .000 \\
\hline & NPF & .000 & & .125 & .000 & .001 & .000 & .000 \\
\hline & GDP & .012 & .125 & & .040 & .024 & .041 & .038 \\
\hline & CAR & .000 & .000 & .040 & & .000 & .000 & .000 \\
\hline & EAT & .000 & .001 & .024 & .000 & & .000 & .000 \\
\hline & TL & .000 & .000 & .041 & .000 & .000 & & .000 \\
\hline & TA & .000 & .000 & .038 & .000 & .000 & .000 & \\
\hline \multirow[t]{7}{*}{$\mathrm{N}$} & PROVISIONS & 15 & 15 & 15 & 15 & 15 & 15 & 15 \\
\hline & NPF & 15 & 15 & 15 & 15 & 15 & 15 & 15 \\
\hline & GDP & 15 & 15 & 15 & 15 & 15 & 15 & 15 \\
\hline & CAR & 15 & 15 & 15 & 15 & 15 & 15 & 15 \\
\hline & EAT & 15 & 15 & 15 & 15 & 15 & 15 & 15 \\
\hline & TL & 15 & 15 & 15 & 15 & 15 & 15 & 15 \\
\hline & TA & 15 & 15 & 15 & 15 & 15 & 15 & 15 \\
\hline
\end{tabular}

Tabel 11. Correlation Variables Growth of Loan

Correlations

\begin{tabular}{|c|c|c|c|c|c|c|c|c|}
\hline & & $T L$ & PROVISIONS & NPF & GDP & DEP & CAR & $\mathrm{TA}$ \\
\hline \multirow[t]{7}{*}{ Pearson Correlation } & TL & 1.000 & .977 & .915 & .464 & .999 & .964 & .999 \\
\hline & PROVISIONS & .977 & 1.000 & .870 & .580 & .976 & .929 & .976 \\
\hline & NPF & .915 & .870 & 1.000 & .317 & .922 & .911 & .922 \\
\hline & GDP & 464 & .580 & .317 & 1.000 & .471 & .466 & .471 \\
\hline & DEP & .999 & .976 & .922 & .471 & 1.000 & .972 & 1.000 \\
\hline & CAR & .964 & .929 & .911 & .466 & .972 & 1.000 & .972 \\
\hline & TA & .999 & .976 & .922 & 471 & 1.000 & .972 & 1.000 \\
\hline \multirow[t]{7}{*}{ Sig. (1-tailed) } & TL & & .000 & .000 & .041 & .000 & .000 & .000 \\
\hline & PROVISIONS & .000 & . & .000 & .012 & .000 & .000 & .000 \\
\hline & NPF & .000 & .000 & & .125 & .000 & .000 & .000 \\
\hline & GDP & .041 & .012 & .125 & & .038 & .040 & .038 \\
\hline & DEP & .000 & .000 & .000 & .038 & & .000 & .000 \\
\hline & CAR & .000 & .000 & .000 & .040 & .000 & & .000 \\
\hline & TA & .000 & .000 & .000 & .038 & .000 & .000 & \\
\hline \multirow[t]{7}{*}{$N$} & TL & 15 & 15 & 15 & 15 & 15 & 15 & 15 \\
\hline & PROVISIONS & 15 & 15 & 15 & 15 & 15 & 15 & 15 \\
\hline & NPF & 15 & 15 & 15 & 15 & 15 & 15 & 15 \\
\hline & GDP & 15 & 15 & 15 & 15 & 15 & 15 & 15 \\
\hline & DEP & 15 & 15 & 15 & 15 & 15 & 15 & 15 \\
\hline & CAR & 15 & 15 & 15 & 15 & 15 & 15 & 15 \\
\hline & TA & 15 & 15 & 15 & 15 & 15 & 15 & 15 \\
\hline
\end{tabular}

